\title{
BEVEZETÖ
}

\author{
(Introduction)
}

\section{ENYEDI GYÖRGY}

A Tér és Társadalom is csatlakozik a honfoglalás millecentenáriumát ünneplőkhöz. Nem világraszóló esemény, hogy egy kis európai nemzet elődei körülbelül 1100 évvel ezelött megtelepedtek a Kárpát-medence ama központi részén, ahol többé-kevésbé ma is élnek. Számunkra kitüntetett jelentőségủ az évforduló. Nemzeti önbecsülésünk fontos forrása annak tudata, hogy a Római Birodalom összeomlása utáni hatalmi-politikai vákuumban először a magyarok hoztak létre tartós államszervezetet a Kárpát-medencében, méghozzá jövevény, nem európai kultúrkőrböl érkezö népként, s igen rövid idő alatt.

Fontos ünnep, de eléggé csendes ünnep: "ni trompette, ni tambour" a francia mondás szerint (sem harsona, sem dobpergés). Mindnyảjunkat föleg a jövő foglalkoztat, bizakodással vegyes aggodalommal. Történelmünk alighanem elágazási ponthoz érkezett: hosszú idő óta elöször nyílt némi esélyünk, hogy a külső erők által formált utak között választhassunk. A választást a történelmi tapasztalatok összegezése könnyítheti. Ezerszáz év történelme a regionális tudomány számára is vizsgálatra érdemes: a földhasználat módja, a városrendszer kiépülése, a közlekedési tengelyek kirajzolódása, az igazgatási térszerveződés évszázadokon át formálódott. Nem tartjuk eröltetettnek, az illendőség egyszerü letudásának ezt a megemlékező számot.

A regionális tudomány szempontjából két fő kérdés fogalmazható meg:

Hogyan illeszkedett be Magyarország Európa térbeli rendjébe?

- Milyen belsö gazdasági térszerkezet és telepulésrendszer formálódott az országban?

\section{A köztes Európában}

A magyarság letelepedési területe hosszú történelme során alig módosult: a Kárpátmedence alföldi-dombsági területeire, belső medencéire terjedt ki. Ez a letelepedési terület különböző államkeretekbe tartozott, $\mathrm{s}$ változott Európán belüli helyzete is. A "történelmi Magyarország" nagyon sok földrajzi alakot öltött - a közfelfogás vagy a Szent István-i királyság területét vagy az Osztrák-Magyar Monarchián belüli 1867 és 1918 közötti Magyar Királyság határait tartja annak.

A honfoglalás elött néhány évszázaddal Európa hatalmi, gazdasági és kulturális központja a Római Birodalom, azaz a Földközi-tenger medencéje volt. Felbomlása után a kontinens súlypontja megkezdte észak-északnyugat felé tartó vándorlását. A korai magyar állam nem esett messze a centrumtól, ahhoz Észak-Olaszországon keresztuil kapcsolódott. Az 1300 és 1800 között eltelt fél évezredben a centrum az Alsó-Rajna vidéken s Flandrián keresztuil jutott el Angliáig, mindig magában foglalva Franciaországot, általában az Atlanti partvonalat, csak átmenetileg az Ibériai-félszigetet, valamint Skandináviát. Hosszabbtövidebb ideig Európa csaknem valamennyi régiója centrum-szerepet töltött be - kivéve Kelet-, Közép- és Délkelet-Európát. Magyarország egész történelme során félperiférikus 
helyzetủ volt, fejlódési útját a mindenkori centrum irányította, a centrum intézményei, gazdasági-társadalmi újításai, eszméi formálták - megkésetten - a hazai folyamatokat. Gyakran használt a "kompország" kifejezés, e füzet egyik tanulmányának címében is fellelhetjük. Hanem hazánk különös komp: nemcsak maga jár a (keleti és nyugati) partok között, a partok is közelednek hozzá, hol keletről, hol nyugatról, attól függỏen, hogy Európa centruma merre helyezödik át.

A félperiférikus helyzet tudomásulvételét a közvélemény nehezen türi, pedig szamár dolog a történelemmel perelni. Jobb egy adott helyzetet racionálisan felismerni, $s$ annak lehetöségeit kiaknázni. Minden nemzet keresi az "ösi dicsöséget", vagy jelen helyzetének vigaszául, vagy legitimizálásául, ám többnyire rossz helyen keresi - egy régen eltünt egykori birodalomban (pl. a görögök Nagy Sándor birodalmában, a szlovákok Nagy Moráviában). Ám az ókori vagy középkori államalakulatok nem hasonlíthatóak a mai nemzetállamokhoz. A határvonalak (pontosabban: határzónák) állandoan változtak, $\mathrm{s}$ egy uralkodó dinasztia befolyásának területét jelölték ki. Amikor "hazánk határát három tenger mosta", nem Magyarországot határolta három tenger, hanem a magyar trónon ülö Anjoudinasztia hatalmi övezetét, melybe Magyarországtól távoli királyságok is beletartoztak. Mátyás király idejét véljük dicsőségünk másik fénypontjának, a szellem és gazdagság központjául szolgáló Budával - ám Budának és Pestnek együtt mintegy 20-25 ezer lakosa volt, annyi mint Danzignak vagy Krakkónak, negyede-ötöde Milánó, Velence lakosságának. Magunk jelentős teljesítménynek tartjuk, hogy a magyarok megkapaszkodtak a Nyugat keleti peremén, a sztyeppei vándornépek közül egyetlenként, nem kerültek vissza sem Kelet-Európába, sem a Balkánra. Kedvezö "kompállás" idején közelebb kerültek a nyugati centrumhoz, keleti közeledés esetén sem oldódtak fel a Keletben. Ne becsüljük le e rengeteg eröfeszítést, s küszködést igényló eredményt!

A korai magyar állam választhatott a nyugati vagy a keleti kereszténység, Bizánc vagy a Nyugat mintája s befolyása között. A két part még nem távolodott el erösen egymástól, s Bizánc választásának is volt esélye. A Nyugat választása az ország sorsát napjainkig ható érvénnyel eldöntötte - a nyugati intézmények, eszmék, innovációk jutottak el hazánkba is. A kontinens innovációs központjához csatlakoztunk, mely hosszú ideig a világ innovációs központja is volt, ezért a centrumhoz viszonyitott elmaradásunk elsösorban idöbeni volt, $\mathrm{s}$ csak részben strukturális jellegü.

A kapitalizmus kialakulása, az ipari-urbánus társadalomra való áttérés hosszú idöszaka keleties jellegü. A feudalizmus felbomlása, a tőke felhalmozása, az elóiparosodás, a városi polgárság elterjedése Nyugat-Európához képest több évszázadot késik. A magyar társadalom még a XX. század elején is falusi, rendies jelkemvonásokat örző - néhány modern szigettel. A kiegyezéstöl az I. világháborúig tartó modernizációs idószak - nyugati közeledés - rövid volt s nem eléggé mélyreható. Az ipari-városi társadalom általánossá válása pedig ismét egy keleties társadalmi formációban, az államszocialista rendszerben következett be.

Fontos következményekkel járt Kelet- és Közép-Európában a nemzetállamok kialakulásának megkésettsége. Nyugat-Európában a XVIII. és XIX. század során alakulnak ki a nemzetállamok - ekkor térségünket soknemzetiségü, pre-modern birodalmak uralják. A nemzetállamok régiónkban a XX. század elején alakulnak ki, jórészt az I. világháborúban vesztes birodalmak feldarabolásával, nem saját szerves polgári fejlödésük, hanem a gyöztes nyugati hatalmak rendelkezései alapján. Modern történelmünket alapvetően befolyásolja, hogy a magyar polgári nemzetállam határait a trianoni békeszerzödés jelölte ki. Ezek a határok a gyöztes hatalmak geopolitikai érdekeit 
fejezték ki, mindenekelött Németország s Szovjet-Oroszország fékentartását; etnikai szempontok a határkijelölésnél alig játszottak szerepet.

A modern Európa kialakulásának évszázadaiban "kompunkat" a nemzetközi áramlatok sodorták, osztoztunk a Habsburg Birodalom sorsában. A II. világháború után kettéosztódó Európa keleti felébe sem önkéntes jelentkezés alapján kerültünk. 1989 után hazánk visszanyerte szuverenitását. Egy kis ország számára az integrálódó világgazdaságban a mozgástér korlátozott, de mégis nyílt némi választási esély. A választás ismét a Nyugathoz történö csatlakozás: nyugat-európai politikai intézmények, gazdasági-szervezési eljárások, eszmeáramlatok honosítása. Ezerszáz éve a Nyugat választása jó elörelátásról tanúskodott; a IX. században még nem volt bizonyos, hogy Nyugat-Európa, a Római Birodalom korábbi északi perifériája kerül a világ gazdasági fejlödésének a középpontjába. A mai választást sok tényezö teszi kézenfekvővé, ám most egy hanyatló, fejlödésében megtorpant központhoz igyekszünk, mely világgazdasági jelentőségébỏl folyamatosan veszít Észak-Amerikával, s fỏleg Kelet-Ázsiával szemben.

\section{A belső térszerkezet}

Az ország belső térszerkezetének formálódását erősen befolyásolta egy nagy szárazföldi medencén belüli fekvése, melyen nem vezettek át jelentös nemzetközi kereskedelmi útvonalak, s gyenge városfejlődése elsősorban a mezőgazdasági termékcseréhez kapcsolódott. A hagyományosan formálódó térkapcsolatok a Kárpát-medencén belül maradtak - egy külsỏ vonal játszott jelentős belsố térformáló szerepet, ez a Duna völgye Alsó-Ausztria és Bajorország irányába. Az időnként fontos észak-olasz vagy lengyel kapcsolatok nemigen hagytak nyomot az országon belül.

Az első ezer évet alapjában az agrárgazdálkodás jellemezte, így a földrajzi munkamegosztás az agroökológiai adottságok különbségeit tükrözte. A medence központi, alföldi részét a XIX. század közepéig az év jelentős részében víz borította, amelyen \$ajátos ártéri gazdálkodás alakult ki. E gazdálkodáson belül nagy szerepe volt a legeltetỏ allattartásnak, mely csak alacsony népsürüséget tudott fenntartani. A földmủvelés legfontosabb térségei a dombvidékek, a Kisalföld és a hegyközi medencék voltak, melyek a legnagyobb agrárnépsủrủséget tartották fenn. A Kárpát-medence mintegy egyharmadát tette ki a hegykeret, melynek népességét a középkorban meginduló bányászat növelte. $\mathrm{Az}$ alapvetően a természeti eróforrások kiaknázására alapozott gazdaság a nagytájak közötti termékcserét szükségessé tette, $\mathrm{s}$ a városképződés - a védelmi, valamint a kormányzati funkciók mellett - elsősorban a nagytảjak érintkezésében kialakult vásárvonalakat követte.

E természeti különbségeket tükröző földrajzi munkamegosztáson a XIX. század lényeges módosulást eredményezett. Kitüntetett jelentőségú volt a folyamszabályozás, mely az Alföld földművelésre alkalmas terulleteit megkétszerezte. Ennek nyomán a múlt §zázadban az Alföld népességnövekedése és városainak gyarapodása jelentősen fellendült, s jelentős gabonafelesleget állított elö, mellyel a Monarchián belüli nagyobb távolságú munkamegosztásba kapcsolódott be.

A XIX. századtól a térszerkezetet az iparosodás, a városrendszer bővülése, a kommunikációs tengelyek kiẻpülése - a helyi gazdaságok nemzetgazdasággá ötvözỏdése formálja. A modern Magyarország térszerkezetének kialakulása már a múlt század második felétől jelentős mértékben államhatalmi beavatkozások eredménye. Állami döntések nyomán alakult ki olyan vasúti vonalvezetés, mely szélsöségesen Budapest központú volt, s mely elsôsorban Nyugat-Európához, továbbá Észak-Olaszországhoz 
kívánta Magyarországot kötni. Céltudatosan épült ki egy túlnyomóan falusi országban egy modern európai nagyváros. Budapest fejlesztését közép-európai regionális központtá a kiegyezés után nemzeti ügynek tekintették. A föváros központú vasúthálózat eleve Budapestre vonzotta a feldolgozó ipart, ehhez járult még a Budapestre szállítás kedvezményes dija. A Fővárosi Közmunkák Tanácsának a mindenkori miniszterelnök volt az elnöke. A vidéki városhálózat formálásában is nagy szerepet játszott a közigazgatás, a közszolgálati intézmények letelepítése.

A XX. század fö térszerkezeti jellemzői a következőek :

- A század elejére már kialakultak a fő kommunikációs tengelyek, ezek vonalvezetésén a gazdaság alapos átalakulása ellenére - nem történt változás.

- Mind a kommunikációs hálózaton, mind a telepưlésrendszeren belül lényeges módosulást okozott a trianoni békeszerződésben foglalt határváltozás, bár a térszerkezet alapvető jellemvonásain - a Budapest központúságon, a nyugat-keleti fejlettségi lejtőn - nem változtatott.

- Kiépült a városrendszer, 1996-ban az ország lakosságának kétharmada városokban él, fél évszázad alatt megtörtént a falusi társadalomról a városi társadalomra való átmenet. A városi népesség-gyarapodás elsősorban a kisvárosi hálózat kibővülésének köszönhetö, hazánk a fejlett országok urbanizációs modelljét követte.

- A fejlett s elmaradott régiók köre gyakran változott a század évtizedeiben, mint ahogyan változott a fejlettség tartalmi meghatározása is. Úgy tủnik, a fejlettség nem irható le egyszerủen gazdasági szerkezettel, inkább a változtatási, alkalmazkodási képességgel, mellyel a gazdaság szerkezete vagy versenyképessége módositható. A fejlesztési tényezők között az eddiginél jobban számításba kell vennünk a helyi társadalom minőségét.

- A magyar gazdaság és társadalom térszerkezete a XX. század nagy részében zárt országhatárokon belül alakult. A két világháború között ezt a szomszéd országokkal fennálló barátságtalan viszony, az államszocialista rendszer idején a nemzetgazdaságok teljes zártsága okozta. 1989, a határok kinyílása után a belsỏ térszerkezet formálásában erösödnek a külső hatások. Ennek jövőbeli lehetőségeit érzékelteti, hogy a 19 magyar megye közül 14 országhatárral is rendelkezik. Újjáledhetnek a Kárpát-medencén belüli hagyományos térkapcsolatok is.

- A XX. század végén a térkapcsolatok formálásában számos új tényezỏ jelent meg, melyek hatásai még nehezen mérhetöek fel. Mindenekelött a telekommunikációs kapcsolatok és azok új információ-továbbítási formái módosithatnak a fơldrajzi fekvés korábbi jelentőségén. Lazulnak a város és vidéke kőzötti munka- és szolgáltatási kapcsolatok is. A német egyesítés óhatatlanul kelet felé mozdította el Európa gazdasági súlypontját - kérdés, hogy ennek lesz-e közvetlen hatása, hiszen a magyar export 40\%át ellenőrző transznacionális gazdasági szervezetek tevékenységüket világméretekben szervezik.

Hatásos lenne a jövőre vonatkozóan a latin jókívánsággal befejezni: sors bona, nihil aliud (jó szerencsét, semmi mást). A szerencse-várás azonban eddig nem sok hasznot hozott. Inkább ajánlom a Biblia-forditó Károli Gáspár szellemi kitartását, a folyamszabályozók mérnöki felkészültségét, a Fövárosi Közmunkák Tanácsának modern urbanisztikai jövőképeit követendö példaként - annak a felismerését, hogy a jővő azé, aki hisz benne, s elméjével, verejtékével munkálkodik rajta. Ezerszáz év története nemcsak a vereségeké, hanem a sikeres újrakezdéseké, felemelkedéseké is. 